\title{
10 Considerations on the role of Hungary and the Hungarian nation in the European Union after 1989
}

\author{
Tadeusz Kopyś
}

\section{Introduction}

Ever since the Hungarian tribes conquered the Carpathian basin 1,100 years ago, the history of Hungary has been that of a small, destroyed nation, one which has continuously struggled to survive. It was conquered by the Tatars, the Ottoman Turks, the Nazis and the Russians. The failed uprisings of 1703 and 1848 against the Hapsburgs and the disaster of the anti-Soviet revolution of 1956 have become deeply rooted in the national psyche. The Treaty of Trianon in 1920 had a similarly serious influence on the formation of the concept of the Hungarian nation in the 20th and 21st centuries. It was so important in shaping Hungarian national identity that, even during the communist dictatorship, the great Hungarian writer Gyula Illyés claimed that anyone who feels the pain of Trianon is a Hungarian. A hundred years later, the wounds of Trianon remain open and unhealed. Many Hungarians consider it an almost personal trauma: unfair, cruel and a source of disputes over the rights of ethnic Hungarians in Romania and Ukraine, which continues to this day. Scholars have almost unanimously placed the origins of modern Hungarian nationalism to the end of the 18th century, alongside the literary works of György Bessenyei and Ferenc Kazinczy, and the resistance of the Hungarian nobility against the decision of Emperor Joseph II to introduce German as an official language throughout traditionally Hungarian-speaking territories. The further development of Hungarian nationalism can be seen as a split process, i.e. as a mass phenomenon (a bottom-up process) and an official nationalism (with a top-down course of action created by the elite). From the 18th century to the end of the interwar period, the concept of the nation was shaped mainly by the aristocracy, a cosmopolitan societal layer which identified poorly with the attributes of the nation's grassroots and focused instead on the idea of progress, European ideas and identifying the nation with the cultural and social trends which prevailed in Europe at the time. Popular nationalism, which is often associated with the figure of Lajos Kossuth, flourished for a brief period during the revolution of 1848. A number of reforms were introduced in 1848 and, with the abolition of serfdom and the restriction of the rights of the nobility, the idea of a common imagined 
community was created for the first time. However, it was expected that every member of this community would be able to speak Hungarian, something which was impossible in an era which also saw the development of Slavic nationalisms. The official Hungarian nationalism in the 19th century can therefore be described as an attempt to enlarge the imagined Hungarian community and to adjust the boundaries of this community to the state borders of the time. ${ }^{1}$

The trauma caused by the disintegration of the integrity of the Hungarian state can be seen as an injustice that disturbed the existing and enduring territorial order, but one can also speak of the conscious or unconscious 'inheritance' of trauma through the generations, something which is related to the idea of social or collective memory. Through the diffusion and subsequent remembrance of a traumatic event, it becomes part of collective memory, which means that a collective trauma can be defined as 'a traumatic event stored in the collective memory'. ${ }^{2}$ The trauma caused by the Treaty of Trianon may be considered the glue which binds the whole nation even closer together. In this sense, one could describe collective trauma as a traumatised image of the self and thus the imagined community. In this sense, it is also interesting to see trauma as an event that, through its force, attacks and even destroys the image of the self, shaking the foundations of the connections between the remembered past, the present and the expected future. ${ }^{3}$

Hungarians also like to describe themselves as ethnically distinct, as an island in a Slavic sea. They perceive themselves to be a separate race: their language is not related to the Indo-European languages that surround them and acts as a powerful glue of national identity. As early as the second half of the 18th century, there has been an ever-present fear of Hungarians assimilating with the other peoples of the region (the Slavs, Romanians and Danube Swabs). This fear contributed to the disastrous policy of assimilating other nations living in the territory of the Lands of the Crown of Saint Stephen in the second half of the 19th century. This was so disastrous because it led to conflict with the Slavic nations living in Hungary and the disintegration of the territory of the historic state in 1920.

The aim of this chapter is to analyse the manner in which nationalism and Hungarian national thought developed after 1989. To do so, however, it is necessary to delve deeper into the history of Hungary and outline the social and political conditions of the development of nationalism in this country. Amongst the Hungarian intelligentsia, there is a growing interest in their national past and the sources of their identity. The popular thesis is that Hungarians are related to oriental peoples and its popularity has grown steadily, having been in use in Hungarian academia for over a century.

\section{The concept of the nation after 1920}

The interwar period and the rest of the 20th century in Hungary constituted a turning point in terms of social, cultural and political change. The division of 
the Hungarian state after the Treaty of Trianon, in which both the territorial character of the country and the psychological state of its citizens changed radically, required a redefinition of Hungarian national identity. For small groups of young intellectuals, both inside and outside Hungary's new borders, it was a period which saw the intense questioning of traditional values and national structures. A new generation of university youth, whose future prospects had been drastically diminished by Hungary's own diminished size and status, were particularly affected by the tensions and conflicts in their socially stratified society; a society which tried desperately to adapt to its radically changed circumstances. Questions about the fate of Hungary, the 'magyar sorskérdés', and the attempts to define the role of the diaspora in the overall understanding of the Hungarian nation, led to the formation of two competing camps: that of folk writers and that of an urban elite or urbánusok. The former referred to the common people of the provinces as a reflection of what was truly Hungarian. The urban camp, based in large cities, referred to European ideas as the basis for Hungarian national identity. According to this camp, modernisation was to be based on the Western European urban model, with an ideology which was not strongly rooted in national identity. As a result, according to their critics, they are not Hungarian enough in either their feelings or understanding of culture. This image of the nation which referred to European values was strongly left wing and liberal, with its authors mainly being intellectuals of Jewish origin. ${ }^{4}$

After 1920, one third of Hungarians found themselves living outside the borders of the new state, constituting an ethnic minority in its neighbouring countries. The population of the country fell from 18.26 million to 7.61 .5 The treaty undoubtedly made the country more ethnically homogeneous. Nationalism in the post-Trianon period developed on two levels. On the one hand, efforts were made to make up for its territorial and demographic losses, leading to support in revisionism, which in turn led to the alienation of the state in the international arena. On the other hand, the elite of the time sought to improve the nation in the civilisational sense. As one politician said, 'we are a small nation, destined to accomplish great things in the spiritual field'. With Count Kuno Klebelsberg as Minister of Education, a cultural policy was launched which contained an extensive public education programme to revive Hungarian national self-awareness after the losses in Trianon. ${ }^{6}$

\section{The political transformation after 1989}

The divisions in the Hungarian elite that have been discernible since 1989 are an inheritance of the interwar period. Already in the 1970s and 80s, two main political camps had resurfaced, ones which also carried with them competing visions of the future of the nation and its place in the surrounding geopolitical reality. In 1987-1988, these camps formed their own political parties: the folk-national camp established the Hungarian Democratic Forum, while the urbánusok formed the Alliance of Free Democrats (SZDSZ) which 
was operational from 1988 to 2013. The Hungarian Democratic Forum and the Union of Free Democrats came to power after 1989, taking turns at the helm of government and with differing perceptions of national and international politics. The Hungarian Democratic Forum (MDF) aimed at the unification of the Hungarian nation, both in the country and abroad. The Forum was founded by intellectuals with a nationalist bent, including Sándor Csoóri, Zoltán Bíró, István Csurka and Sándor Lezsák. They referred to the ideological tradition of the népi-nemzeti ('populist' or 'rural-national') movement, which had been opposed to the urbánus ('urban') school of thought since the 1920s. The Forum focused on national and cultural traditions, aiming at fostering radically democratic, bottom-up politics and a 'third way' between capitalism and communism. A representative of this party, Prime Minister József Antall, the ruling centre-right government in 1990-1994, described himself as the prime minister of 15 million Hungarians in Central Europe (meaning the Hungarian diaspora in neighbouring countries, as well as those within the country).

In Hungary, the belief prevails that whoever sets the tone of the "national discourse' has the right to control the state - including the constitution and lawmaking. In the first free elections, the parties which alluded to the nation the most emerged victorious. The 1990 elections were won by the MDF, the main party of the national opposition to communism. SZDSZ, meanwhile, was composed mainly of dissidents from the former democratic opposition and reformed socialists who had held power before 1989. The first democratically elected government after 1989 began with a strong nationalist tone, with Prime Minister József Antall stating that he represented 15 million Hungarians, while the population of the Hungarian state was only 10 million. Interestingly, Antall referred to the Hungarian diaspora in neighbouring countries, but did not challenge the status quo or initiate a claims policy to reunite Hungary's pre-war areas. ${ }^{7}$ When, in the early 1990s, the leader of the far-right Hungarian Justice and Life Party, István Csurka, attacked the government's conservative policy and commitment to the rule of law, Antall replied: 'Membership of the Hungarian Democratic Forum is only open to those who are committed to both the nation and the rule of law'. ${ }^{8}$ In contrast to Orbán and Antall, those on the left and liberals have accepted the legalcivic conception of the nation. This vision meant accepting the current state of affairs and striving to guarantee the right of the Hungarian minority to express its national consciousness, language and traditions as secured under the treaty. This dualism was a consequence of the divisions which had already existed in the interwar period (the folk writer and urban camps). Now, it is clearly discernible in two very different concepts in Hungarian politics: state building and nation building. ${ }^{9}$

\section{Fidesz and its new policy of national unity}

The first important step in building a national identity was the adoption in 2001 of the Hungarian Card (a document under the Hungarian Charter 


\section{Tadeusz Kopyś}

that granted a number of privileges to its holders from countries such as Romania, Ukraine or Serbia) and the 2004 referendum on the extension of Hungarian citizenship to all Hungarians of ethnic origin living outside Hungary. On 5 December 2004, a referendum was held in Hungary to gauge the public attitude towards the concept of granting dual citizenship to Hungarian citizens living abroad. The idea was to give Hungarians living abroad the opportunity to enjoy Hungarian rights and social benefits related to EU citizenship, as well as a sense of belonging to the Hungarian nation. Ultimately, however, the lively debate which ensued and the politics of disinformation and criticism of the referendum by left-wing parties led to a mass boycott of the referendum: only $37 \%$ of those eligible to vote took part, which made it invalid. The referendum initiative came from a nationalist group, and Fidesz adopted it mainly for tactical reasons. The referendum's motto was 'We can finally heal the wounds of Trianon'. The referendum failed because the then socialist-liberal government waged a populist counter-campaign, pretending to protect the social achievements of poor Romanian Hungarians, and people continued to fear Fidesz because they suspected that dual citizenship was simply a costly whim of the right and a ploy to gain an additional electorate for Fidesz abroad, a suspicion which was borne out later. The referendum was declared invalid, which led Fidesz to blame left-wing and liberal parties for being 'traitors to the national cause'. After the electoral defeat of the socialist party and the victory in the Hungarian parliamentary elections in 2010, Fidesz won two-thirds of the seats in parliament (the disproportionate electoral system gave the right-wing coalition $52.7 \%$ of the votes and $68 \%$ of the seats in parliament). ${ }^{10}$ When Fidesz took power again in the first session of the new parliament, it passed a dual citizenship law. Ninety years after the signing of the Treaty of Trianon, 4 June was paradoxically declared the Day of National Unity, something quite characteristic of contemporary, mainstream Hungarian nationalism. The new prime minister, Viktor Orbán, introduced the 'National Cooperation Programme' and Fidesz launched a programme of constitutional reform, lowering the requirement of a majority of four-fifths of the parliament to amend the constitution to twothirds, and consistently weakening any legal institutions that might seek to control or limit the government's actions. The main rationale for replacing the previous constitution was that it ran counter to individual rights as opposed to the interests of the national community, and therefore was unable to express 'Hungarian national values' strongly enough. ${ }^{11}$ The new government introduced a new constitution in April 2011 and its controversial provisions resulted in an avalanche of reports and comments from the press, academics, the Venice Commission, the United States, the European Parliament, NGOs and human rights defenders. This raised concerns in the European Union about human rights and the concept of the tripartite division of powers. Fidesz's electoral success violated the sacred canons of 
left-liberal consensus. The overwhelming electoral victory had a sobering effect for those who felt that history had ended with the triumph of liberal democracy. The new authorities emphasised that Hungarian problems should only be solved with the use of Hungarian methods and with due regard to the unique nature of Hungary's development.

Some analysts have claimed that the 'Trianon syndrome' is also useful for nationalist populists who want to present themselves as defenders of the nation. Few do it better than the ruling Fidesz party of Prime Minister Viktor Orbán. After 2010, the desire intensified to create a capitalist class supporting this movement, something which is an attribute of classical populists. Hence the position of Attila Antal, who classifies Orbán's policy as 'elite right-wing populism', seems to be correct. It is characterised by the fact that its politics favours the elite and the upper middle class through its social policy, while softening discontent, defending sovereignty, criticising foreigners, and intensifying the constant sense of danger or threat. ${ }^{12}$ Hence, Hungarian nationalism does not mean a reorientation towards racism, fascism or xenophobia, nor is it ethnic in a cultural or biological sense. Before the 1998 elections, Orbán's party used rhetoric that was a loose mixture of liberalism, Christian Democrat and national ideas, seeking to establish a civic Hungary based on the middle classes. Orbán rejected neoliberalism, with which he identified the then ruling coalition of socialists and liberals, proposing a homegrown version of modernisation in its place.

Easing restrictions and barriers to Hungarian citizenship led to divisions among the Hungarian diaspora into 'good Hungarians' and those who did not sympathise with Hungarian right-wing politics and policies. The granting of electoral rights to the diaspora meant that Hungary's political arena expanded beyond its borders and is now also being played out in neighbouring countries. Almost all of Orbán's important messages are based on the idea of 'national unification', which has both symbolic and literal meanings and is employed in both foreign and domestic policy. In terms of the former, the prime minister explicitly criticised Trianon, as well as the legacy of the communist system and the impact of globalisation; forces he believed were the top political issues to be addressed prior to 2010. In terms of domestic politics, 'national reunification' refers to the 'system of national cooperation' (a set of 'unconventional' policies combining statism, economic nationalism, protectionism and neoliberalism) that has proven to be an alternative to liberal democracy. ${ }^{13}$ Sharing voting rights with representatives of an external national minority is one of the most controversial tools for maintaining bonds with citizens abroad. Extending the electoral law to encompass the diaspora is important both symbolically and pragmatically. Symbolically, by making voting available to those who do not live in the country, it means recognising external citizens as fully fledged members of a political community or as political actors in their former homeland, which is still understood in terms of a state, albeit an imagined one. ${ }^{14}$ 


\section{The Eastern (Asian) turn in the conception of the Hungarian nation in the 21st century}

When assessing the issue of globalisation, the Fidesz leadership believes that nation states will prevail in the future. If we look at Asia - as the leaders of Hungary claim - there are no common actions, no common currencies - but rather both small and large countries that are doing very well. Moreover, in terms of the development of economies or states, we should also consider the development of national values since building a pan-European community ultimately leads to their erosion. On the other hand, the Jobbik party and its leader, Gábor Vona, support the idea of abandoning Eurototalism in favour of Eurasianism (linking Hungary with political and economic alliances with the great states of Asia)..$^{15}$

In June 2001, the Hungarian parliament adopted a law on the rights of national minorities, which became known as the Hungarian Charter, and which attracted the attention of both European officials and researchers working on nationalism. In Central Europe, governments including the Austrian, Croatian, Romanian and Slovakian had also passed laws that granted various forms of preferential treatment to members of their own diasporas living in other countries. The Hungarian Card is therefore an example of a nationbuilding strategy that can be defined as 'virtual nationalism'. As an alternative to the traditional concept of the nation state, it aims to include ethnically related people in the concept of the nation and to offer them a number of unique rights, a potentially controversial notion in the European Union.

Trans-sovereignty, or 'virtual nationalism', aims to create institutions that link people across national boundaries. This option abandons the idea of border changes, insists that the political community should be based on national identity without the need to create a nation state. The second Fidesz government, established in 2010, passed the Dual Citizenship Act, which is another important step in the implementation of the Hungarian trans-sovereign nation-building strategy. The law provided for citizenship on demand for those who do not live in their home country. Granting citizenship to representatives of a national minority resulted in the transformation of the definition of the national interest to include not only the interests of resident Hungarian citizens, but also the interests of those who constituted a national minority abroad. ${ }^{16}$

The act granting dual citizenship entered into force in January 2011. It gives all persons who can prove that their ancestors came from the Greater Hungary area the right to obtain Hungarian citizenship. It therefore makes it possible to obtain dual citizenship for people living outside Hungary, and there is no requirement to move to Hungary, which should apply to Hungarian minorities living in neighbouring countries. ${ }^{17}$ Shortly thereafter, an amendment to the law requested by Jobbik provided that foreigners naturalised in this way had the right to participate in elections in Hungary. Neighbouring countries reacted nervously to the new law. The Slovak authorities expressed concern 
about the lack of dialogue and cooperation with the Hungarian government in drafting its law on citizenship. The Fidesz party was founded in 1988, but did not become one of the most important parties in the country until 19982002. Especially before the 2010 elections, Orbán and Fidesz focused their policies on shaping a new concept of the Hungarian nation, with the party's elites focused on building national cohesion. Against this political framework, the subject of the Treaty of Trianon returned to the fore. A second tendency was to discredit and delegitimise the liberal side of the political scene as hostile to the people (nation).$^{18}$ Even during his first administration, Orbàn was clearly revisionist and spoke of creating an economic living space in the Carpathian basin and of taking steps to secure at least one autonomous territory for Hungarians living abroad. It seems that Fidesz did not make any revisionist demands, but the very use of slogans referring to the past, to a Greater Hungary, or at least an allusion to it, by the politicians of this party was something new for voters. It seems that the leader of Fidesz used some slogans in his programme that were taboo in Hungarian politics before 1989. An element of this rhetoric was the Lands of the Crown of Saint Stephen and, ${ }^{19}$ after 2010, the commemoration of the infamous Trianon Treaty returned. As part of their strategy to counteract internationalisation, Fidesz leaders introduced a National Unity Day (Nemzeti Összetartozás Napja) shortly after winning the elections, marking the anniversary of the Trianon peace treaty by means of a symbolic rejection of it. ${ }^{20}$

Most of the Hungarian political elite between 1989 and 2001 were aware that support for any revisionist projects (particularly any related to the revision of the 1920 borders) would be unacceptable in Europe, which was also confirmed by the poor public support for the far-right Hungarian Justice and Life Party (MIÉP). This new, one could say Hungarian, model rejects the idea of territorial revision and the repatriation of the diaspora to the homeland. This model uses EU law that places considerable emphasis on the rights of national minorities, and instead of restoring the nation state, it creates nation-centric and centre-dependent institutions that maintain and reproduce the nation beyond existing state borders. ${ }^{21}$ They do this through a myriad of support programmes for schools abroad, by providing jobs and hospitals for members of the diaspora, creating companies that enable the diaspora to grow and remain in their ancient territories (e.g. in Slovakia and Transylvania). On the path of such a development controlled from the centre - such as Budapest - Hungarian communities abroad have a chance for the first time in many decades to rebuild demographically, to arrest their assimilation and reduce internal and external migration.

From the moment of its adoption, the Hungarian Card was clearly the most coherent attempt to formulate virtual, cross-border nationalism. Anyone obtaining the card was entitled to a number of privileges in their home country. The large number of card applicants indicated that the legislation was met with a high demand. In Romania, 700,000 cards had been issued by mid-July 2003. These numbers suggest that a large part of the 
ethnic Hungarian population outside of Hungary maintains the concept of a common Hungarian nationality, despite the separation of these territories from Hungary in 1918-1920.

In the minds of the creators of the Hungarian Card, the government, supported by the right-wing Fidesz and Jobbik parties, is continuing a policy which is in line with the concept of a 'cultural nation'. This means that every Hungarian is part of the Hungarian nation, no matter where they live, providing they remain faithful to the Budapest government. Fidesz was the first political party to establish personal relations with ethnic Hungarians abroad and these networks helped Fidesz to formulate its policy in such a way that ethnically related people aboard were able to take centre stage in the new concept of the nation. Fidesz's party structures boast the largest number of Hungarians from neighbouring countries and it was these ethnic Hungarians who emphasised the need to institutionalise ties with their homeland. This was done, inter alia, by establishing the Office for Hungarians Abroad (Határon Túli Magyarok Hivatala). Moreover, other elements binding together Hungarians are the World Federation of Hungarians and the Bethlen Gábor Foundation. Fidesz was the first to formulate a comprehensive policy towards its national minority abroad, something which gave it an advantage over leftliberal opposition parties. ${ }^{22}$

After 2010, the government introduced a law allowing the Hungarian diaspora to participate in elections in Hungary. On the one hand, this is a very generous action by the government, and on the other hand, it gives Fidesz a significant advantage in the next elections. In 2014, $95 \%$ of Hungarians living abroad voted for Fidesz..$^{23}$ After 2010, Fidesz took over the role of the party of the entire Hungarian nation, and, representing Hungary and the entire nation abroad, denied this role to others. According to this theory, there is one nation, so one political option should represent it. As part of this approach to diaspora issues, however, an illustrative dualism emerged that manifested itself in two points of view on national issues: a left-wing and a right-wing one. ${ }^{24}$

This approach to national issues became an element used in gauging how representatives of individual political factions tackled some important political issues, and even those related to Hungarian foreign policy. In other words, the divisions in the assessment of national issues was in effect a division into the forces that represented the nation and those that could not, would not or did not want to represent it at all. The vision of Europe described as the Orbán model is of a 'Christian Europe of sovereign states' and an 'illiberal democracy'. Hungary's position on the future of the European Union, repeatedly expressed in many political fora, can be called the Hungarian model of the EU. The newly adopted amendment to the Basic Law of Hungary, with the obligation of the state to protect Christian culture and potential to restrict certain fundamental rights, strengthens the role of religion in the constitutional legitimacy of the concept of an ethnic nation. In this concept, the nation, as the subject of the Basic Law, is not only a community of ethnic Hungarians, but also a Christian community, which means that those who 
do not associate themselves with Christianity may also feel excluded from the nation. In this constitutional order, the state does not necessarily have to tolerate all religions, and adherents of Christianity may feel entitled to intolerance towards representatives of other religions. ${ }^{25}$

In Orbán's speech in Baile Tusnad in July 2018, the Hungarian Prime Minister raised several important aspects regarding the future of Europe and the region. Most importantly, he confirmed the need to 'build a Central Europe' where the local culture differs from that of Western Europe. In this sense, the region is more important than the entire Union. In another speech, on 26 July 2012, Orbán explained why authoritarianism is needed in treating the Hungarian malaise: 'Joining forces is not a matter of intention, but pure strength. In the case of a semi-Asian party like ours, there is no other choice'. This assessment is very similar to that of the late Imre Kertész, a Nobel laureate in literature, who argued that Hungary's misfortune was due to its inability to choose between Asia and Western Europe. Even so, religion (religions) had not influenced the shaping of the national idea in the same way as in Poland, for example. Under communism, the Roman Catholic Church was neither a symbol of national independence nor a source of protection for the Hungarian opposition.

Prime Minister Orbán is critical of the West yet remains a pragmatist at heart and appreciates the opportunities offered by the European Union to Hungary. In the eyes of many Hungarian intellectuals, what has happened in the last twenty or thirty years - since socialism turned into liberal democracy - was a success story until Fidesz took power in 2010. The country is seen as having been embraced by Putinisation, authoritarian politics and a staterun economy, which in fact leads to the belief that the country has never been truly democratic and may never shake off its legacy of selfish nationalism and paternalistic state socialism. Orbán, himself vice-president of the European People's Party, expressed his view on Europe in the following terms: 'We want to live in Europe as Hungarians'. The Fidesz leader did not present the EU as a threat to Hungary, but he also did not unconditionally support all of the ideas coming from Brussels. Since 2010, Orbán has waged a 'war of independence' against Brussels. Taking advantage of the traditional Hungarian resentment towards the great powers and the West, he successfully directed part of the Hungarian electorate against the Commission and the bureaucracy of the European Union. Even though Orbán was among the first to demand the withdrawal of Russian troops in 1989, he is now a pro-Russian politician and promoter of close cooperation with Asian states. He has put a great emphasis on national sovereignty in EU decision-making, and is also critical of EuroAtlantic relations and the United States. ${ }^{26}$ His 'soft Euroscepticism' relies on a particular critique of the West and neighbouring countries in order to achieve things which are in the national interest. Paradoxically, Orbán also strives to achieve greater integration with Hungary's EU neighbours. This affords Budapest the potential to build a 'transnational' nation and, simultaneously, greater odds that Union institutions will defend the Hungarian 
national minority. ${ }^{27}$ Naturally, the Fidesz leader is not an advocate of the open accession of its neighbours to various international bodies, as Ukraine can readily attest. When an educational act was passed in Kiev in 2017 that allegedly harmed the interests of the Hungarian national minority in Ukraine, Hungary began to block the process of Ukraine's integration with NATO.

The Hungarian vision of the European Union is ideological and should be seen in Eurosceptic and conservative terms. The main elements of this model are the concept of 'Christian democracy' or 'illiberal democracy'. The second element of the Hungarian vision of Europe and the place of the Hungarian nation in it is a 'provincial' approach to Central and Eastern Europe. It is based on an aversion to the Trianon Treaty and a recognition of the cultural diversity of Central and Eastern Europe and the Western part of the continent (alongside a radical rejection of multiculturalism). Another aspect of Budapest's activities is its immigration policy, which is similar to the policy of the German authorities in accepting ethnic Germans expelled from various Central European countries after 1945. According to Zsuzsa Csergő and James Goldgeier, if a Hungarian politician ${ }^{28}$ were to be asked what the concept of their nation's development is, they would probably answer that it is a 'Europe of the regions' with many centres of power and various forms of loyalty. Hence, for Hungarians and their diaspora in Central Europe, Budapest acts as a centre of national culture, but on the other hand, centres in Bratislava, Belgrade and Bucharest are those in the which the diaspora is loyal to the state in which they live. There are also regional centres such as Košice (Hungarian: Kassa), Kolozsvar, Nowi Sad (Hungarian: Szabadka). Such a concept of the nation and multi-level centres of sovereignty and loyalty appeared, according to some researchers, in the Middle Ages. ${ }^{29}$ Diaspora community building is similar to the nation-building process: it is about 'creating and maintaining contacts with Hungarian minority populations in the region to promote a common identity. ${ }^{30}$

The third element of the Hungarian model is the pursuit of close cooperation with Russia, Turkey, China and other Asian countries, based on intensive economic relations and the proposal to provide EU security guarantees to some member states. Ethnonationalism, referring to tribal traditions, is akin to a substitute for religion. ${ }^{31}$ The radical right (e.g. Jobbik) is decidedly anti-Israel, pro-Palestinian and anti-American. However, interestingly and perhaps uniquely amongst Hungarian political parties, it is also pro-Syrian, anti-Western, pro-Russian and pro-China. The party also advocates closer ties with other countries such as Kazakhstan. Jobbik wants to create a 'sacral alternative' for the Hungarian electorate in the form of various pre-Christian pagan cults. Neo-Turanism is, therefore, a source of the formation of new layers of national pride, a specific code (alongside runic script), one which is incomprehensible to others and legible only to Hungarians and the diaspora, it is a form of mysticism and exoticism. These traditional values found their way perfectly in the modern world because they are propagated via a number of websites: kuruc.info and barikad.hu. In turn, emerging ethnic myths such as 
Euroasianism and Turanism raise questions about how deeply they should be interpreted. Should Hungary support relations with China, or should it stand up for their Uighur and Tibetan 'relatives' oppressed by the Beijing regime? The theory of Turanism accords the role of a bridge between East and West to Hungary, filling its adherents with pride in their past, a sense of independence, and a desire to find the true nature of the nation which is poised on the border between two worlds. This eastern ethnogenesis seemed to fit perfectly with the trends prevailing in the global economy after the 2008 crisis. Prime Minister Viktor Orbán stated after 2010: 'To be powerful, a person must be proud of his national identity (...) In Europe, the Hungarians are the most western eastern nation (...) and today it is an honour to be called an oriental nation'. ${ }^{32}$

\section{Hungary within the European Union}

The fourth element in the Hungarian vision of the EU is a far-ranging pragmatism. Hungary is a moderately Eurosceptic country, with the Hungarian variant taking a very pragmatic form which exploits many of the opportunities afforded by membership of the European Union. Hungarians are one of the European nations which treat national identity as superior, as one which surpasses European identity. As many as 51\% of Hungarians rate their identification as 'Hungarian' higher than others and concomitantly this diminishes the sense of belonging to the European Union. A further $44 \%$ articulate an attachment to national traditions but also of belonging to Europe. Only $1 \%$ of the Hungarian population declares themselves as 'Europeans' above all other sources of identification. Hungarians are only somewhat proud of their national achievements as a collective (less than $50 \%$ ) but, on the other hand, they are very proud of the achievements of their athletes and artists (over 90\%). According to sociological research, the approach to European and national-Hungarian identities and the assessment of sporting success depends on the region of residence. The Hungarian government has been accused of trying to virtualise its borders, of paying only lip service to the political borders of Hungary. In fact, the Hungarian government seeks to exert its power to influence Hungarians in Romania, Slovakia and Ukraine in the political (through the participation of Hungarians abroad in Hungarian elections), cultural and educational fields. As a result, the Hungarian government has strongly supported, and continues to support, the membership of all its neighbours in the European Union.

The refugee crisis in Europe in 2015 showed, in the opinion of some observers, the intolerance of the Hungarian government. ${ }^{33}$ At the beginning of the crisis, Prime Minister Viktor Orbán stated that 'Christian culture is a unifying force for the nation'. He went on to claim that 'Hungary will either be Christian or not at all'. In another speech, in early September 2015, Orbán went further, stating that 'The Christian-national idea will regain its predominance not only in Hungary but throughout Europe' ${ }^{34}$ Christianity and religion serve as 
reference points which Orbán's brand of right-wing populism uses selectively to build its political narrative. Fidesz, once a liberal party, began to move to the right side of the political scene from the mid-1990s, openly adopting a positive attitude towards religion. Fidesz uses religious symbols and employs them alongside pre-Christian pagan traditions. This is reflected in the concept of the 'two Hungaries', two very different traditions that are derived respectively from Western Christianity and an older pagan legacy, one which dates back to the tribal period. According to the current political elite, the legendary Turul bird, a symbol of ancient, pre-Christian Hungary, is the most representative symbol of national identity, an image which gave birth to Hungary. Fidesz interprets these pre-Christian traditions within the framework of nationalism, and this ethnonationalism provides a sufficient basis for political identification as a kind of substitute religion. The crown of Saint Stephen is another powerful symbol of contemporary Hungary. Particularly noteworthy is the manner in which the authorities reconciled the worship of the "holy crown' and pagan traditions after 2010. The crown, upon its return from the USA in January 1978, was placed by the communist Hungarian authorities of the time in the National Museum, where it was just another museum exhibit. It grew in importance, however, during the first Fidesz government. In 2000, along with the sceptre, orb and coronation sword, the crown of St Stefan was transferred to the Dome Hall of the Hungarian Parliament. It has become an image and symbol of the unity of the once broken Hungarian nation. In exceptional cases, the crown is transported by boat to Esztergom, the seat of the Archbishop of Hungary (for example, it was transported on 15 August 2001, on the feast of the Assumption of the Blessed Virgin Mary). However, in March 2012, Oiuna Adigzi See-Oglu, a shaman from the Russian republic of Tuva, ${ }^{35}$ was invited to the Hungarian parliament, and who cleansed and rededicated the crown of St. Stefan in a new place in parliament. This took place despite the negative position of the Catholic church in Hungary towards neopaganism. ${ }^{36}$ In 2012, during a visit to Kazakhstan, the Hungarian governmental delegation presented their hosts with a shamanic world tree. ${ }^{37}$

Fidesz has managed to combine anti-elitism, nationalism and an antiEuropean stance with a pragmatic approach in most areas of policy, presenting a charismatic leadership that allegedly defends national interests and those of ordinary people.

Populism does not have a specific and enduring ideological content but is rather characterised by an anti-elite approach to politics that seeks to foster mass political mobilisation and mass participation in the political process. Populism, therefore, can develop any ideology which serves to unite and homogenise the nation. ${ }^{38}$ The influence of populism is also clearly discernible in Hungarian foreign policy. The current Hungarian government is pro-Russian (with the idea of the Eurasian Union backed by its coalition partner, Jobbik) and often uses history to reinforce its position towards Brussels. The apogee of this anti-EU rhetoric is the commemoration of the Hungarian freedom fighters of 1956, combined with criticism of the West, which failed to help 
Budapest fight off Soviet intervention. On 25 February 2017, Viktor Orbán declared that the ideas that led to the oppression of the 20th century had sprung up in Western minds, that both communism and National Socialism were intellectual products of the West. On the same occasion, the Minister of Human Resources, Zoltán Balog, even argued that effective and constructive dialogue between post-socialist states and Western Europe could only be established if the latter 'was willing and able to look at the sins of both communism and Nazism as a European shame'.

Hungary's growing economic dependence on Russia has contributed to a certain ambivalence towards its communist past, and the authorities have only orchestrated what might be termed 'limited de-Russification'. Since 2014, Fidesz has tried to bring the EU closer to Russia, attempting to secure Russian support for projects that the EU opposes. The best example of such actions was the controversial decision to expand the Paks nuclear power plant, which Hungary will eventually be able to implement thanks to Russian funds, despite initial opposition from the European Commission. The policy of ambiguous gestures does not make Fidesz popular in Europe either. When Hungary took over the presidency of the Council of the EU, a carpet adorned with a map of Greater Hungary greeted guests to the council building as soon as they entered. ${ }^{39}$ During the political crisis in Crimea, the conflict between Russia and Ukraine, Prime Minister Orbán came up with the idea that the Hungarian minority in Ukraine should also be able to decide for themselves and have the right to obtain Hungarian citizenship. As a result, the authorities in Budapest quickly came to be called 'Russia's Trojan Horse in the European Union'. ${ }^{40}$

Orbán has frequently stated that the timeworn political distinction between the left and the right is no longer meaningful. Fidesz has begun to see itself as the repository of national values and interests and its efforts in this regard have been greatly aided by the inability of those on the left to develop an authentic interpretation of the concept of the nation. Fidesz's political concept can be described as a mobilising form of conservatism, one aimed at strengthening solidarity and loyalty based on national identity. This ideology assumes that national issues are typically ignored or underestimated by the state and thus aims to redress the balance in order to ensure the primacy of the nation. This approach takes for granted that, in order to achieve national goals, the nation should even be superior to the state. It was only after 2002 that Fidesz managed to crystallise the party's programme around this ideology. ${ }^{41}$

From this point on, the emphasis on the nation became dominant: the nation began to be regarded as the ultimate source of legitimacy. In doing so, Fidesz scored points over its rivals for their perceived lack or insufficient development of national policy in their programmes. In contrast, Fidesz advocated a cultural interpretation of the concept of the nation under which the relationship between the state and the individual was of secondary importance: belonging to a nation and citizenship are two separate dimensions. Fidesz conservatives believe that the nation provides a more important source of legitimacy than 
that which stems from the political games played out in parliament. Fidesz has taken the position that power in the state can only be legitimised by the will of the nation..$^{42}$ A key assumption in the post-1989 concept of the Hungarian nation is that it is no longer divided and separated by the borders established after 1920. If we treat the nation as a political category, there is only one Hungarian nation: the community of Hungarian citizens who live together. If any (individually) or even all (of course, also individually) Hungarians living abroad want to become members of this national political community, there are procedures to facilitate this. Members of this community can even move to Hungary, where they can obtain Hungarian citizenship after some time.

\section{Conclusions}

The evolution of Hungarian nationalism after 1989 is closely intertwined with its national past. The 'trauma of Trianon' is felt across the political spectrum in Hungary, and Prime Minister Orbán has used these emotions over the past decade in his efforts to show Hungary as a resurgent nation and to contain migrants and the alleged 'globalist influence'. After 1989, a renaissance of national issues has also been observed in Hungary, previously a taboo subject prior to the political transformation. No political alternative (including the left) has defined its attitude to the past, memory, diaspora issues and national identity. It seems that belonging to the European Union has made it easier for the Magyars to maintain contact with their diaspora, allowing them to appeal to international political forums in the defence of Hungarians in countries such as Romania and Slovakia.

In recent years, there has also been a renaissance in Hungarian Turanism, represented especially by Jobbik, a party which is also anti-Western. Jobbik is very critical of both the international policy of the European Union or the United States. Hungary is considered a victim of Western politics, a country which, as a result of Western policy, has the largest national minority in Europe. Jobbik's politicians also strongly criticise globalism, liberalism. Therefore, the 'eastern turn' seems to be a retreat from the West. On the other hand, the migration crisis in Europe might become an obstacle for Hungarians in their attempts to foster better relations with certain Asian nations.

\section{Notes}

1 Benedict Anderson, Imagined communities. Reflections on the Origin and Spread of Nationalism, (Verso 1983), 73-77, 101-106.

2 Jeffrey C Alexander, 'Toward a Theory of Cultural Trauma', in Jeffrey C Alexander, Ron Eyerman, Bernard Giesen, Neil J Smelser, Piotr Sztompka (eds), Cultural Trauma and Collective Identity, (University of California Press 2004), 22-23.

3 Susan Brison, 'Trauma Narratives and the Remaking of the Self', in Mieke Bal, Jonathan V Crewe, Leo Spitzer (eds), Acts of memory. Cultural recall in the present, (Dartmouth College Press 1999), 39-54. 
4 Gábor Gyáni and György Kövér, Magyarország társadalomtörténete. A reformkortól a második világháborúig, (Osiris Kiadó 2004), 384.

5 Tamás L Vizi, A sérelmi politizálástól a nemzeti összetartozásig. Trianon, revizió, határkérdés, nemzetegyesítés 1920-2010, (CEPOLITI Kiadó 2016), 10-11.

6 István Mészáros, 'Klebelsberg Kunó, az iskolareformer', in István Zombori (ed), Gróf Klebelsberg Kunó emlékezete, (Gróf Klebelsberg Kuno Alapítvány 1995), 49-50.

7 Gergely Egedy, 'Conservativism and Nation-Models in Hungary', (2013), 4, Hungarian Review, 3, 68-72.

8 József Antall, 'Az MDF legyen középpárt' in Modell és valóság, (Budapest 1994), vol II, 9-10.

9 Egedy, (n 7), 71.

10 Miklós Bankuti, Gábor Halmai, Kim Scheppele, 'Disabling the constitution', (2012), 23, Journal of Democracy, 3, 139-140.

11 Gyula Tellér, Rendszer-e a rendszerváltás rendszere?, (2009), 54, Nagyvilág, 11, 982-987.

12 Attila Antal, A populista demokrácia természete, (Napvilag Kiadó 2017), 246-249.

13 Umut Korkut, Liberalization Challenges in Hungary: Elitism, Progressivism, and Populism, (Palgrave 2012), 172-175.

14 Peter J Spiró, 'Perfecting Political Diaspora', (2006), 81, New York University Law Review, 1, 102-155.

15 Mark Bassin, Gonzalo Pozo, The Politics of Eurasianism: Identity, Popular Culture and Russia's Foreign, (Rowman and Littlefield 2017), 254-256.

16 Zsuzsa Csergö and James M Goldgeier, 'The European Union, the PostCommunist World and the Shaping of the National Agendas', http://aei.pitt.edu/ id/eprint/3004 accessed 12 May 2020.

17 Andreas Koob, Holger Marcks, Magdalena Marsovszky, 'Größenwahn im Karpatenbecken. Die ungarische Rechte und ihr Blick nach Außen', in Mit Pfeil, Kreuz und Krone. Nationalismus und autoritäre Krisenbewältigung in Ungarn, (Unrast Verlag 2013), 158-159.

18 Lászlo L Balogh, 'Trianon-Stationen und Statuen des Schmerzes', in Harald Dionys Gröller and Harald Heppner (ed), Die Pariser Vororte-Verträge im Spiegel der Öffentlichkeit, (Transkulturelle Forschungen an den Österreich-Bibliotheken im Ausland 2013), 61-63.

19 Koob, Marcks, Marsovszky, (n 17), 155-195.

20 Magdalena Marsovszky, 'Geschlossene Gesellschaft. Zu den ideologischen Hintergründen der völkischen Entwicklung in Ungarn', in Andreas Koob, Holger Marck, Magdalena Marsovszky (eds), Mit Pfeil, Kreuz und Krone. Nationalismus und autoritäre Krisenbewältigung in Ungarn, (Unrast Verlag 2013), 13-57.

21 Zsuzsa Csergő and James M Goldgeier, 'Nationalist Strategies and European Integration', (2004), 2, Perspectives on Politics, 1, 21-37.

22 Nándor Bárdi, 'A Külhoni Magyarok és a Magyarországi Kormányzati Politikák', in Ervin Gömbös (ed), A Kisebbségek Jövöje a Globalizálódó Világban, (Magyar ENSZ Társaság 2016), 21-34.

23 http://magyarforum.hu/cikk/231/65-orszag-magyarjai-igenyeltek-a-kettos-allam polgarsagot accessed 23 May 2020.

24 Ildiko Szabó, 'A nemzet fogalmi konstrukciója a Fidesz diskurzusaiban 1998 es 2006 között', (2007), 16, Politikatudomány Szemle, 3, 145-150. 


\section{Tadeusz Kopyś}

25 'Minden magyar a turulba születik' [All Hungarian Are Born Into the Turul Bird] Népszabadság, (Budapest, 29 September 2012).

26 Péter Tölgyessy, 'A Fidesz és a magyar politika lehetséges új iránya', in Zsolt Bod and András Körösényi (ed), Van irány? Trendek a magyar politikában, (Hungarian Acedemy od Sciences Press 2012), 332-337.

27 After the 2014 European Parliamentary elections, the Hungarian nation is also represented by Hungarians from Romania and Slovakia, with the election of László Tőkés from Transylvania and László Gubík from Slovakia. The creation of a unified Hungarian nation became a reality.

28 Of course, the answer we get to this question will depend on the political orientation of the given politician.

29 Zsuzsa Csengő and James Goldgeier, 'Nationalist Strategies and European Integration', 27, www.researchgate.net/publication/231890449_Nationalist_ Strategies_and_European_Integration accessed 31 May 2020.

30 Ibid., 4.

31 Ibid., 2-3.

32 'Hungary ready to open a new chapter of Hungarian-Turk cooperation', www. kormany. hu/hu/a-miniszterelnok/hirek/magyarorszag-keszen-all-a-magyar-turkegyuttmukodes-uj-fejezetenek-megnyitasara accessed 26 May 2020.

33 As Prime Minister Orbán explained, 'Our [migration T K] policy is to help where there is trouble, not to bring trouble to Europe (...) We believe that large numbers of Muslims will necessarily lead to the emergence of parallel societies, because Christian and Muslim communities will never come together'. Orbán believed that the elite of the 'European empire' was ruled by bureaucrats who were not elected by anyone. According to Orbán, these elites are detached from their national roots. For more, see www.tvp.info/35519891/viktor-orbn-o-przyjmowaniu-uchodzcowpostrzegamy-ich-jako-muzulmanskich-najezdzcow accessed 23 May 2020.

34 András Bozóki and Zoltán Ádám, 'State and Faith: Right-wing Populism and Nationalized Religion in Hungary', (2016), 1, East European Journal of Society and Politics, 2, 98-122.

35 The Republic of Tuva borders Mongolia and is therefore far from the ancestral homeland of the Finno-Ugric peoples, that is, the eastern slopes of the Urals and the Khanty-Mansi Autonomous Okrug.

36 The mages known as taltós, who practised their rites until the 19th century, can be considered remnants of shamanism in Hungary. The interest in this side of the Hungarian tradition dating back to the times of the Magyar migrations began in the 18th century, with the first Hungarian scholars travelling to the Turkish countries and when the first non-scientific research into the anthropology and ethnology of the Magyars took place. The first researcher to tackle the subject of shamans was Vilmos Diószegi, who dealt with this subject in the 1950s in the then Soviet Union.

37 The World Tree occurs in various variants, even in Siberia itself, e.g. Tungusians believe that there are as many world trees as there are main worlds. The concept of the world according to Hungarian shamanism is also different - whilst it is presented in the form of a tree which is common enough in Europe, in contrast to the rest of the continent, the division of the world is vertical (eastern world evil, western world - good). Wiesław Bator, Drzewo sięgajace nieba: szamanizm $i$ dyfuzjonizm w węgierskiej baśni magicznej, (Nomos 1987). 
38 Nadia Urbinati, Democracy Disfigured. Opinion, Truth, and the People, (Harvard University Press 2014), 108-110.

39 In December 2016, during a meeting of the Hungarian Diaspora Council, he spoke about the fact that all parts of the Hungarian nation, once 'broken by the dictates of Trianon', had finally found themselves. After: Dominik Héjj, 'Węgry 2010-2017. Ile jest populizmu w reżimie Viktora Orbána?', in Filipa Pierzchalski and Bartosz Rydliński (eds), Autorytarny populizm w XXI wieku. Krytyczna rekonstrukcja, (Dom Wydawniczy Elipsa), 139.

40 www.atlanticcouncil.org/in-depth-research-reports/report/kremlin-trojan-horses accessed 2 March 2020.

41 In 2002, after losing the elections, Fidesz reacted to the defeat by turning to more radical populism. Its nationalism also became more pronounced and more clearly directed against the left. In his famous speech after losing in the first round, Orbán said: 'For us, our family, our children, our human dignity, our freedom, our faith and our country are important things in life (...). Now we must defend them (...). We Hungarians, we have nowhere to withdraw. Our opponents have revealed their true nature (...). If we do not stand firmly behind the ideas we believe in, Hungary will become their playground. Let us not allow it (...). This nation, this country is our homeland'. See József Debreczeni, Arcmás, (Noran-Libro Kiadó 2009), 299.

42 Umut Korkut, Liberalisation Challenges in Hungary: Elitism, Progressivism and Populism, (Palgrave 2012), 162-168. 